\title{
Elemental bio-imaging of thorium, uranium and plutonium in tissues from occupationally exposed former nuclear workers
}

\begin{tabular}{|r|l|}
\hline Journal: & Analytical Chemistry \\
\hline Manuscript ID: & ac-2009-02650w.R1 \\
\hline Manuscript Type: & Article \\
\hline Complete List of Authors: & $\begin{array}{l}\text { Hare, Dominic; UTS } \\
\text { Tolmachev, Sergei; bUnited States Transuranium \& Uranium } \\
\text { Registries } \\
\text { James, Anthony; bUnited States Transuranium \& Uranium } \\
\text { Registries } \\
\text { Bishop, David; UTS } \\
\text { Austin, Christine; Univerisity of Technology Sydney,, Institute for } \\
\text { Nanoscale Technology } \\
\text { Fryer, Fred; Agilent Technologies } \\
\text { Doble, Philip; Univesity of Technology, Sydney, Department of } \\
\text { Chemistry and Forensic Science }\end{array}$ \\
\hline \hline
\end{tabular}

\section{(5) ScholarONE" \\ Manuscript Central}


Elemental bio-imaging of thorium, uranium and plutonium in tissues from occupationally exposed former nuclear workers

Dominic Hare ${ }^{a}$, Sergei Tolmachev ${ }^{b}$, Anthony James ${ }^{b}$, David Bishop $^{a}$, Christine Austin $^{a}$, Fred Fryer ${ }^{c}$, and Philip Doble ${ }^{* a}$

${ }^{a}$ Elemental Bio-imaging Facility, University of Technology, Sydney, Broadway, New South Wales, Australia.

${ }^{b}$ United States Transuranium \& Uranium Registries, College of Pharmacy, Washington State University, Richland, Washington, USA.

${ }^{c}$ Agilent Technologies Australia, North Ryde, New South Wales, Australia.

\begin{abstract}
Internal exposure from naturally occurring radionuclides (including the inhaled long-lived actinides ${ }^{232} \mathrm{Th}$ and ${ }^{238} \mathrm{U}$ ) is a component of the ubiquitous background radiation dose ${ }^{1}$. It is of interest to compare the concentration distribution of these natural $\alpha$-emitters in the lungs and respiratory lymph nodes with those resulting from occupational exposure, including exposure to anthropogenic plutonium, depleted and enriched uranium. This study examines the application of laser ablation-inductively coupled plasmamass spectrometry (LA-ICP-MS) to quantifying and visualizing the mass distribution of uranium and thorium isotopes from both occupational and natural background exposure in human respiratory tissues, and for the first time, extends this application to the direct imaging of plutonium isotopes. Sections of lymphatic and lung tissues taken from deceased former nuclear workers with known history of occupational exposure to specific actinide elements (uranium, plutonium or americium) were analyzed by LA-ICP-MS. Using a previously developed LA-ICP-MS protocol for elemental bio-imaging of trace elements in human tissue and a new software tool, we generated images of thorium $\left({ }^{232} \mathrm{Th}\right)$, uranium $\left({ }^{235} \mathrm{U}\right.$ and $\left.{ }^{238} \mathrm{U}\right)$ and plutonium $\left({ }^{239} \mathrm{Pu}\right.$ and $\left.{ }^{240} \mathrm{Pu}\right)$ mass distributions in sections of tissue. We used a laboratory-produced matrix-matched standard to quantify the ${ }^{232} \mathrm{Th},{ }^{235} \mathrm{U}$ and ${ }^{238} \mathrm{U}$ concentrations. The plutonium isotopes ${ }^{239} \mathrm{Pu}$ and ${ }^{240} \mathrm{Pu}$ were detected by LA-ICP-MS in $65-\mu \mathrm{m}$-diameter localized regions of both a paratracheal lymph node and a sample of lung tissue from a person who was occupationally exposed to refractory plutonium (plutonium dioxide). The average (overall) ${ }^{239} \mathrm{Pu}$ concentration in the lymph node was 39.2 $\mathrm{ng} / \mathrm{g}$, measured by High Purity Germanium (HPGe) $\gamma$-spectrometry ${ }^{2}$. Localized mass concentrations of thorium $\left({ }^{232} \mathrm{Th}\right)$ and uranium $\left({ }^{238} \mathrm{U}\right)$ in lymph node tissue from a person not occupationally exposed to these elements (chronic natural background inhalation exposure) ranged up to 400 and $375 \mathrm{ng} / \mathrm{g}$, respectively. In lung samples of occupationally non-exposed to thorium and uranium workers, ${ }^{232} \mathrm{Th}$ and ${ }^{238} \mathrm{U}$ concentrations ranged up to 200 and $170 \mathrm{ng} / \mathrm{g}$, respectively. In a person occupationally exposed to
\end{abstract}


air-oxidized uranium metal ${ }^{3}$, the maximum ${ }^{235} \mathrm{U}$ and ${ }^{238} \mathrm{U}$ isotopic mass concentrations in a lymph node, measured at higher resolution (with a 30- $\mu \mathrm{m}$ laser spot diameter), were 70 and $8500 \mathrm{ng} / \mathrm{g}$, respectively. The ratio of these simultaneously measured mass concentrations signifies natural uranium. The current technique was not sufficiently sensitive, even with a $65-\mu \mathrm{m}$ laser spot diameter, to detect ${ }^{241} \mathrm{Am}$ (at an overall tissue concentration of $0.024 \mathrm{ng} / \mathrm{g}$, i.e., $3 \mathrm{~Bq} / \mathrm{g}$ ).

\section{Introduction}

Since its inception in 1968 as the National Plutonium Registry, the United States Transuranium and Uranium Registries (USTUR) has been quantifying individual exposures to actinide elements and following health outcomes in nuclear industry workers ${ }^{4}$. The mission of the USTUR is to study occupationally exposed workers from the point of exposure to death. The USTUR measures the uptake, translocation and retention (biokinetics) of plutonium, americium, uranium, and other actinides. The USTUR is also a national and international resource for testing and improving the application of excreta monitoring and other contemporary bioassay data to predict tissue dose rates measured at autopsy. Registered workers were mostly employed at weapons sites. They received substantial accidental intakes of plutonium, americium and/or uranium, since as far back as the Manhattan Project (1944-46). The USTUR and the associated National Human Tissue Repository (NHRTR) is a unique resource for preserved tissues and radiometric analysis data - linked to individual-specific health physics monitoring data, health records and pathology findings. To date, USTUR is the custodian of tissue radioanalysis data (and preserved tissue samples) from 325 donors - including 36 whole-body donors.

Elemental bio-imaging (EBI) is a potential application of laser ablation-inductively coupled plasma-mass spectrometry (LA-ICP-MS) for the determination of actinide distributions in human tissue samples. Briefly, a focused laser beam is directed onto the surface of a tissue sample, and the ablated material is transported to the ICP-MS by a carrier gas. By traversing the laser beam across the sample, the resultant mass spectra can be combined into two-dimensional maps displaying the relative intensity of measured isotopes throughout the tissue section. Quantitative data can be recorded by the ablation of matrixmatched tissue standards and construction of multi-point calibration curves. We have previously described the use of EBI in the elemental analysis of Parkinsonism animal models ${ }^{5}$, human osteoarthritic tissue $e^{6}$ and human melanoma samples ${ }^{7}$.

Traditionally, the measurement of plutonium $\left({ }^{238,239+240} \mathrm{Pu}\right)$ and americium $\left({ }^{241} \mathrm{Am}\right)$ in biological samples has relied upon radiometric analysis. Radiochemical methods for the analysis of human tissues, previously reported by both the USTUR and the Russian Dosimetry Registry of the Mayak Industrial 
Association (DRMIA), require dry/wet ashing and dissolution in mineral acids followed by radiochemical separation and alpha-spectrometric detection of the actinides ${ }^{8}$. A similar method was used to measure the plutonium content of tissues and bones from residents of Tokyo (Japan) ${ }^{9}$.

For the past decade, ICP-MS has been established as a method for actinide bioassay, e.g., to measure the concentrations of uranium isotopes in urine for both environmental ${ }^{10-12}$ and occupational exposures ${ }^{13}$, as well as environmental thorium and uranium in blood ${ }^{14}$. Recently, the application of ICP-MS for fast bioassay of plutonium in feces has also been described ${ }^{15}$.

LA-ICP-MS has been applied to the imaging of uranium $\left({ }^{238} \mathrm{U}\right)$ and thorium $\left({ }^{232} \mathrm{Th}\right)$ in plant materials ${ }^{16}$, human brain tumour resections ${ }^{17}$, human hippocampus sections ${ }^{18}$, and in coronal rat brain sections ${ }^{19}$. It was unclear if environmental exposure or another external source accounted for the presence of uranium and thorium in brain tissue.

This paper reports the first use of LA-ICP-MS for in situ imaging of the actinide elements ${ }^{238} \mathrm{U},{ }^{235} \mathrm{U},{ }^{232} \mathrm{Th}$, ${ }^{239} \mathrm{Pu}$, and ${ }^{240} \mathrm{Pu}$ in human lymph node and lung tissues. The LA-ICP-MS method presented in this study did not require extensive or potentially biohazardous sample preparation (as is required for radiometric analysis), yet it does enable concentration measurements of actinides in human tissues to be made at low $\mathrm{ng} / \mathrm{g}$ levels.

\section{Experimental}

Instrumentation

All experiments were carried out using a New Wave UP-213 laser ablation unit (Kenelec Technologies, Mitcham, Victoria, Australia). The UP-213 emits a $213 \mathrm{~nm}$ laser pulse from a Nd:YAG solid state gain medium. The laser unit was connected to an Agilent Technologies 7500ce ICP-MS (Forrest Hill, Victoria, Australia) with a 'cs' lens system for enhanced sensitivity. The LA-ICP-MS system was tuned for maximum sensitivity prior to each experiment using NIST 612 Trace Elements in Glass. NIST glass was also used to ensure low oxide production. The $248 / 232\left(\mathrm{ThO}^{+} / \mathrm{Th}^{+}\right)$ratio was consistently less than $0.3 \%$. Typical operational parameters are given in Table 1.

The laser energy density was maintained at $0.3 \mathrm{~J} \mathrm{~cm}^{-2}$. This laser power minimized fracturing of the tissue due to vaporization of water. The laser frequency was $20 \mathrm{~Hz}$. Laser spot diameters were selected to ensure a good balance between image resolution and sample runtime, which was up to 24 hours, depending on the sample size. 
Solution nebulisation (SN)-ICP-MS was performed for the analysis and quantification of the matrixmatched tissue standards that were employed for quantification of the samples. These experiments were performed on a separate Agilent 7500 ce ICP-MS fitted with an I-AS autosampler (Agilent, Australia). A $250 \mathrm{ppb}$ solution of ${ }^{103} \mathrm{Rh}$ was used as the reference element that was added to each sample via a peristaltic pump and T-piece connector. A quartz concentric nebulizer and Scott-type spray chamber (Glass Expansion, Australia) were used. Helium was used as a collision gas to remove polyatomic interferences. Parameters are outlined in Table 1.

Table 1: SN / LA-ICP-MS operational parameters.

\begin{tabular}{|l|l|l|l|l|}
\hline \multicolumn{2}{|l|}{ Agilent 7500ce ICP-MS } & \multicolumn{2}{l|}{ New Wave UP213 Laser Ablation } \\
\hline & LA & SN & Wavelength, $\mathrm{nm}$ & 213 \\
\hline Rf Power, W & 1200 & 1500 & Repetition frequency, $\mathrm{Hz}$ & 20 \\
\hline Cooling gas flow rate, $\mathrm{L} \mathrm{min}^{-1}$ & 15.0 & 15.0 & Laser energy density, $\mathrm{J} \mathrm{cm}^{-2}$ & 0.3 \\
\hline Carrier gas flow rate, $\mathrm{L} \mathrm{min}^{-1}$ & 1.1 & 0.8 & Spot size, $\mu \mathrm{m}$ & 30,65 \\
\hline Sample depth, $\mathrm{mm}$ & 6.0 & 8.0 & Scan rate, $\mu \mathrm{m} \mathrm{s}$ & 30,65 \\
\hline QP Bias, V & -5.0 & -5.0 & Line spacing, $\mu \mathrm{m}$ & 30,65 \\
\hline OctP Bias, V & -8.0 & -8.0 & Carrier gas & $\mathrm{Ar}$ \\
\hline Scan mode & \multicolumn{2}{|c|}{ Peak hopping } & Monitored at $30 \mu \mathrm{m}, \mathrm{m} / \mathrm{z}$ & $232,235,238$ \\
\hline Dwell time, $\mathrm{s}$ per $\mathrm{m} / \mathrm{z}$ & 0.1 & 0.1 & Monitored at $65 \mu \mathrm{m}, \mathrm{m} / \mathrm{z}$ & $232,235,238,239,240,241$ \\
\hline Extracts 1;2, V & $6.8 ;-126$ & $0 ;-125$ & & \\
\hline Collision gas & None & $\mathrm{He}$ & & \\
\hline
\end{tabular}

Human tissue sample preparation for EBI

Samples frozen at $-30^{\circ} \mathrm{C}$ (the standard protocol for long-term storage of NHRTR tissues) were de-frosted and fixed in $10 \%$ buffered formalin for preservation during shipment. Human tissue samples ( 2 samples of lung tissue and 3 lymph nodes) were received from USTUR (Table 2).

Table 2. USTUR tissue samples by case number and primary exposure element

\begin{tabular}{|c|l|c|c|}
\hline USTUR Sample \# & \multicolumn{1}{|c|}{ Tissue description } & Weight (g) & Primary exposure nuclide \\
\hline 246.610 & Lung (R) - Superior Lobe & 3.22 & $\mathrm{Am}$ \\
\hline 303.007 & LN Tracheobronchial (R) & 0.92 & $\mathrm{Pu}$ \\
\hline 407.002 & LN Paratracheal (R) & 0.26 & $\mathrm{Pu}$ \\
\hline 407.630 & Lung (R ): Inferior & 1.36 & $\mathrm{Pu}$ \\
\hline 1060.304 & LN Parabronchial (L) & 0.12 & $\mathrm{U}$ (natural) \\
\hline
\end{tabular}

For LA-ICP-MS measurements, the shipment formalin was decanted and samples were frozen in isopentane/liquid nitrogen and mounted in Tissue-Tek OCT freezing media (ProSciTech, Kirwan, Queensland, Australia). Samples were then sectioned at $30 \mu \mathrm{m}$ on a cryostat using C.L. Sturkey Diamond PTFE-coated 
disposable microtome blades and mounted on high-purity StarFrost microscope slides (ProSciTech). After sectioning, the remaining tissue samples were returned to the buffered formalin solution for preservation. Prepared sample sections were ablated at ambient temperature.

\section{Thorium and uranium quantification procedure}

The quantification method for thorium and uranium was adapted from Hare et al. ${ }^{5}$ as follows. Chicken breast tissue was obtained from a local market and was stripped of all fatty and connective tissue using a PTFE-coated scalpel. Approximately $5 \mathrm{~g}$ portions of the tissue were spiked with volumes of $100 \mathrm{mg} / \mathrm{L} \mathrm{Th}$ and $\mathrm{U}$ standards in $5 \% \mathrm{HNO}_{3}$ (Choice Analytical, Thornleigh, NSW, Australia) as listed in Table 3. A further volume of $5 \%$ Seastar Baseline grade $\mathrm{HNO}_{3}$ (Choice Analytical) was added to a final mass of $6 \mathrm{~g}$ to aid homogenization. Homogenization was performed using an OmniTech TH tissue homogenizer fitted with polycarbonate probes (Kelly Scientific, North Sydney, NSW, Australia). Six aliquots (ca. $100 \mathrm{mg}$ ) of accurately weighed homogenized tissue were then digested in 4:1 $70 \%$ Baseline $\mathrm{HNO}_{3}$ (Choice Analytical) and Ultrapure $31 \% \mathrm{H}_{2} \mathrm{O}_{2}$ (Merck, Kilsyth, Victoria, Australia) using a Milestone MLS 1200 closed vessel microwave digester. The digests were gravimetrically diluted to ca. $50 \mathrm{~g}$ with $18.2 \mathrm{~m} \Omega$ deionised $\mathrm{H}_{2} \mathrm{O}$. These digests were quantified by solution nebulisation ICP-MS. Standards for quantification were prepared from fresh $1000 \mathrm{ppm}$ stocks (Choice Analytical) to determine the total uranium and thorium content of the digests (including any $U$ and Th endogenous to the sample prior to spiking). The \%RSD for the 6 aliquots was calculated $(<5 \%)$ to ensure homogeneity. These standards were then packed into 1 $\mathrm{cm}^{2}$ histology moulds, frozen in liquid nitrogen/isopentane and sectioned on a cryostat. Calibration curves for LA-ICP-MS were constructed by ablating representative areas of each of the standards prior to the analysis of each sample.

Table 3: Spiked volumes and final concentrations of matrix-matched tissue standards.

\begin{tabular}{|l|l|l|}
\hline & Approximate spiked volume of $\mathbf{1 0 0} \mathbf{~} \mathbf{g} / \mathbf{L}$ standard solution $(\boldsymbol{\mu L})$ & Final concentration $\mathbf{( n g} / \mathbf{g})$ \\
\hline \multirow{2}{*}{ Th } & 10 & 171.8 \\
\cline { 2 - 3 } & 100 & 1537 \\
\hline \multirow{2}{*}{$\mathbf{U}$} & 10 & 130.9 \\
\cline { 2 - 3 } & 100 & 1812 \\
\hline
\end{tabular}

Qualitative analysis of plutonium isotopes

${ }^{239,240} \mathrm{Pu}$ isotopic standard solutions are not currently availability in Australia. Therefore, the results are presented as the raw signal intensity values (cps) for $\mathrm{m} / \mathrm{z}=239,240$. 
Image construction

A laser spot size of $65 \mu \mathrm{m}$ and scan speed of $65 \mu \mathrm{m} \mathrm{s}^{-1}$ was used in all cases, except USTUR Case 1060 (occupational exposure to uranium) for which a laser spot size of $30 \mu \mathrm{m}$ and scan speed of $30 \mu \mathrm{m} \mathrm{s} \mathrm{s}^{-1}$ were also used to produce higher resolution images. The MS integration time was set in each experiment to ensure true image resolution was as close to $65 \mu \mathrm{m}$ (or $30 \mu \mathrm{m}$ ) as possible. Images were subsequently produced using in-house ISIDAS (Interactive Spectral Imaging Data Analysis Software) suite written in Python programming language to reduce all MS scan data into two-dimensional images. These images were exported from ISIDAS as Visualization Toolkit (.vtk) files into the MayaVi2 (Enthought, Inc., Austin, Texas, USA) for final image rendition.

Sample case descriptions

USTUR Case 0407

This gentleman was employed at the Rocky Flats Plutonium Fabrication Plant in Colorado, USA from 1958 to $1975^{20}$. In 1965 he was involved in an extensive plutonium fire incident. Examination of the plutonium fire aerosol showed that the material was highly refractory (insoluble) and this was avidly retained in the lungs. For this reason intravenous chelation therapy with calcium diethylenetriaminepentaacetic acetate (Ca-DPTA) was ineffective, and the Registrant was reassigned to non-plutonium work. There is no record of this registrant having worked with uranium or thorium. He passed away in 2008 at age 90+ years from heart failure. This Registrant was a whole body donor and the lung and lymph node samples studied here were taken at autopsy.

USTUR Case 0303

Case $0303^{21}$ was employed for 30 years at the Hanford complex. He was involved in several minor plutonium exposures and a major exposure in 1968, when he punctured his protective glove and cut his finger on Pu-contaminated equipment. The wound was heavily contaminated with soluble plutonium. Tissue surrounding the wound was excised and intravenous administration of Ca-DPTA enhanced his urinary excretion of plutonium. He did not work with uranium. The Registrant died in 2008 at age 87 . A tracheobronchial lymph node (taken at autopsy) was studied here.

USTUR Case 0246

This Registrant was employed at the Hanford nuclear materials complex in Washington, USA for 25 years $^{22}$. In 1976 an ion-exchange column containing approximately $100 \mathrm{~g}$ of ${ }^{241} \mathrm{Am}$ that he was working on 
exploded, causing him severe acid burns and cuts to his face and upper body. Intravenous Ca-DPTA treatment was commenced promptly, followed by several years of intravenous Zn-DPTA chelation therapy. The Registrant died in 1987 at 75 years of age, from emphysema. Prior to his accidental ${ }^{241} \mathrm{Am}$ exposure, he had suffered a myocardial infarction and coronary artery disease. A right lung superior lobe (taken at autopsy) was studied here.

\section{USTUR Case 1060}

This Registrant worked at the Hanford complex for 40 years, where he was chronically exposed to uranium from 1948 to 1950 whilst working in the uranium melt plant ${ }^{23}$. The form of the uranium was most likely $\mathrm{U}_{3} \mathrm{O}_{8}$. Urinalysis suggested there was a single acute incident of uranium exposure occurring in 1948 in addition to chronic $U$ dietary intake. This Registrant was also involved in several plutonium contamination incidents and was potentially exposed to elevated airborne plutonium concentrations on two occasions, but only one urine measurement exceeded the minimum detectable activity (MDA) for plutonium. The Registrant died (in 2008) at age 83, of a cerebral infarct due to thrombosis of the left carotid artery. A left parabronchial lymph node (taken at autopsy) was studied here.

\section{Results and discussion \\ Plutonium exposure \\ USTUR Case 0407}

Figure 1 shows a light micrograph and images of $\mathrm{m} / \mathrm{z} 232,238,239$ and 240 in the paratracheal lymph node from Case 0407. Lateral image resolution was $65 \mu \mathrm{m}$. The $\mathrm{m} / \mathrm{z} 239$ and 240 images represent ${ }^{239} \mathrm{Pu}$ and ${ }^{240} \mathrm{Pu}$, respectively. The relative intensities of the 239 and 240 signals are consistent with ${ }^{240} \mathrm{Pu} /{ }^{239} \mathrm{Pu}$ atom ratio $(0.02-0.08)$ expected for weapons grade plutonium ${ }^{24}$. From $\gamma$-spectrometric measurements, the average ${ }^{239} \mathrm{Pu}$ concentration in the whole lymph node was estimated to be $39 \mathrm{ng} / \mathrm{g}$. ${ }^{241} \mathrm{Am}$ was not detected by LA-ICP-MS as the average ${ }^{241} \mathrm{Am}$ concentration $(0.2 \mathrm{ng} / \mathrm{g})$ estimated by $\gamma$-spectrometry was below the estimated $1 \mathrm{ng} / \mathrm{g}$ detection limit of the instrument. The signal at $\mathrm{m} / \mathrm{z}=239$ was solely due to ${ }^{239} \mathrm{Pu}$ and not the ${ }^{238} \mathrm{UH}^{+}$isobaric ion, as a signal at 239 was not detected in other samples with high concentrations of ${ }^{238} \mathrm{U}$ such as Case 1060 ( $8500 \mathrm{ng} / \mathrm{g}$ ).

Figure 1 clearly indicates inhomogeneous distribution of all measured actinides in the lymph node, with very similar localization of ${ }^{232} \mathrm{Th}$ and ${ }^{238} \mathrm{U}$ (presumably from chronic natural background inhalation exposure) to that of anthropogenic ${ }^{239} \mathrm{Pu}$ and ${ }^{240} \mathrm{Pu}$ (from occupational exposure). The measured ${ }^{232} \mathrm{Th}$ concentration ranged up to $300 \mathrm{ng} / \mathrm{g}$. 
An inhomogeneous actinide distribution was also found in the lung (Figure 2). This lung segment from the inferior right lobe shows two distinctive areas of signal at $\mathrm{m} / \mathrm{z}=239$, with no corresponding signal recorded for $m / z=240$. Figure 3 shows that the location of the $m / z=239$ signal $\left({ }^{239} \mathrm{Pu}\right)$ from acute accidental inhalation was correlated with that of $\mathrm{m} / \mathrm{z}=232\left({ }^{232} \mathrm{Th}\right)$ from chronic background inhalation.

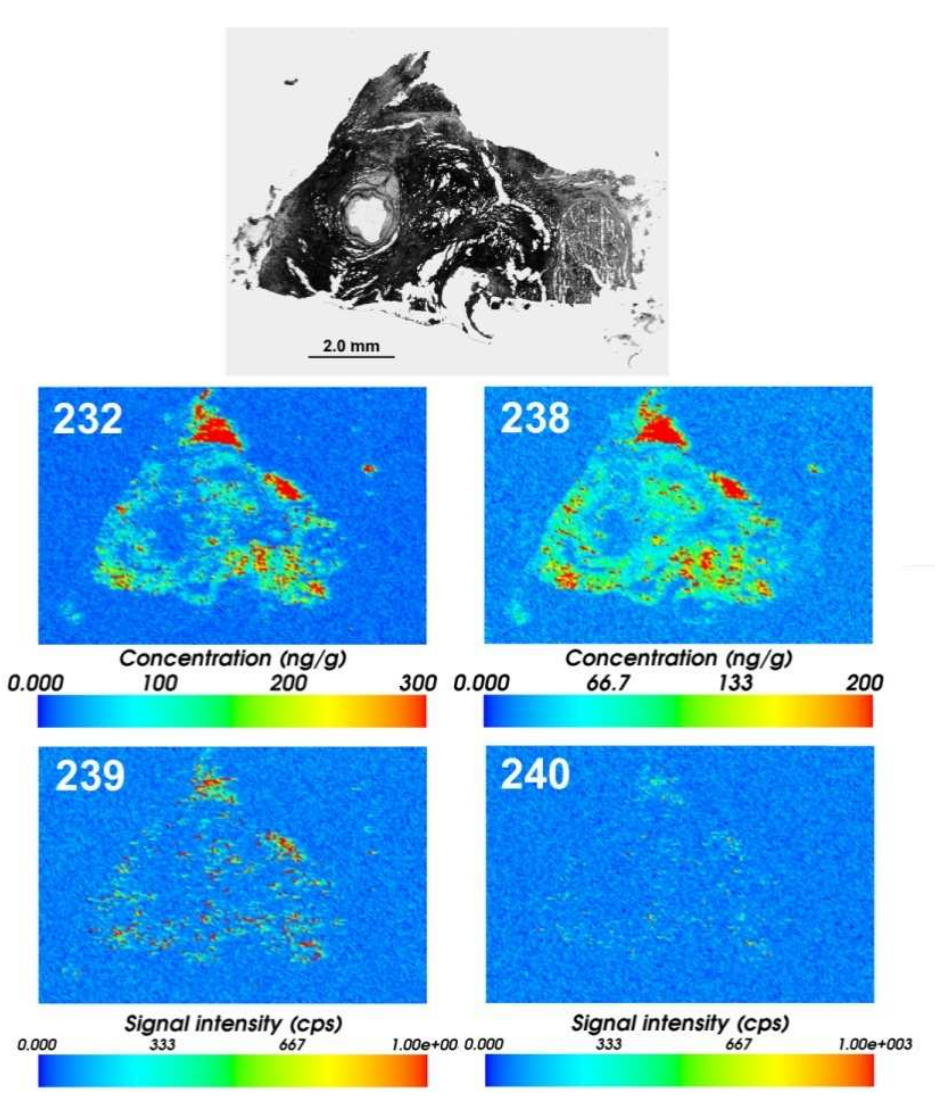

Figure 1: Photomicrograph (top) and $\mathrm{m} / \mathrm{z} 232,238,239$ and 240 images (65- $\mu \mathrm{m}$ scan spot) of paratracheal lymph node from USTUR Case 0407. 

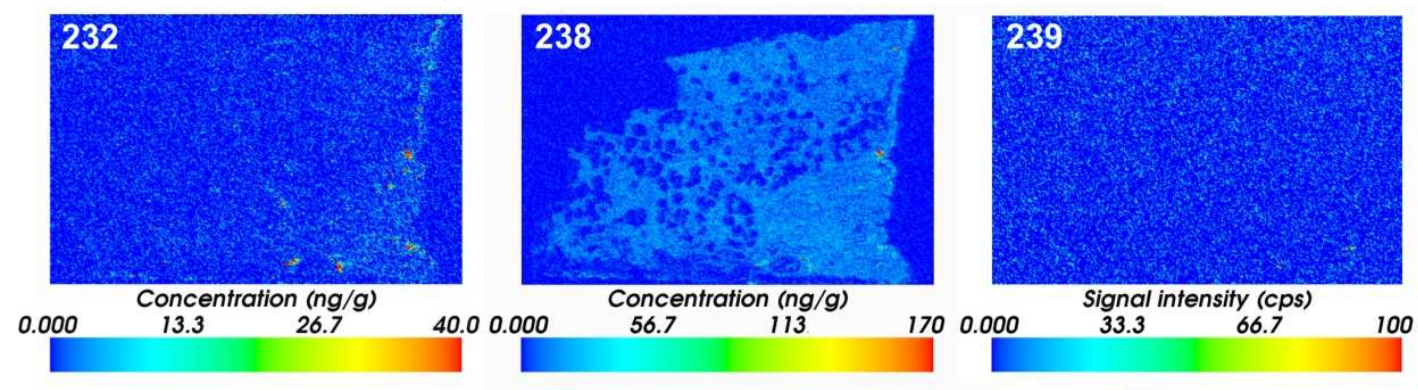

Figure 2: Photomicrograph (top) and 232, 238 and 239 images (65- $\mu \mathrm{m}$ scan spot) from inferior right lung segment (approx. $3 \mathrm{~cm}$ long) from USTUR Case 0407.

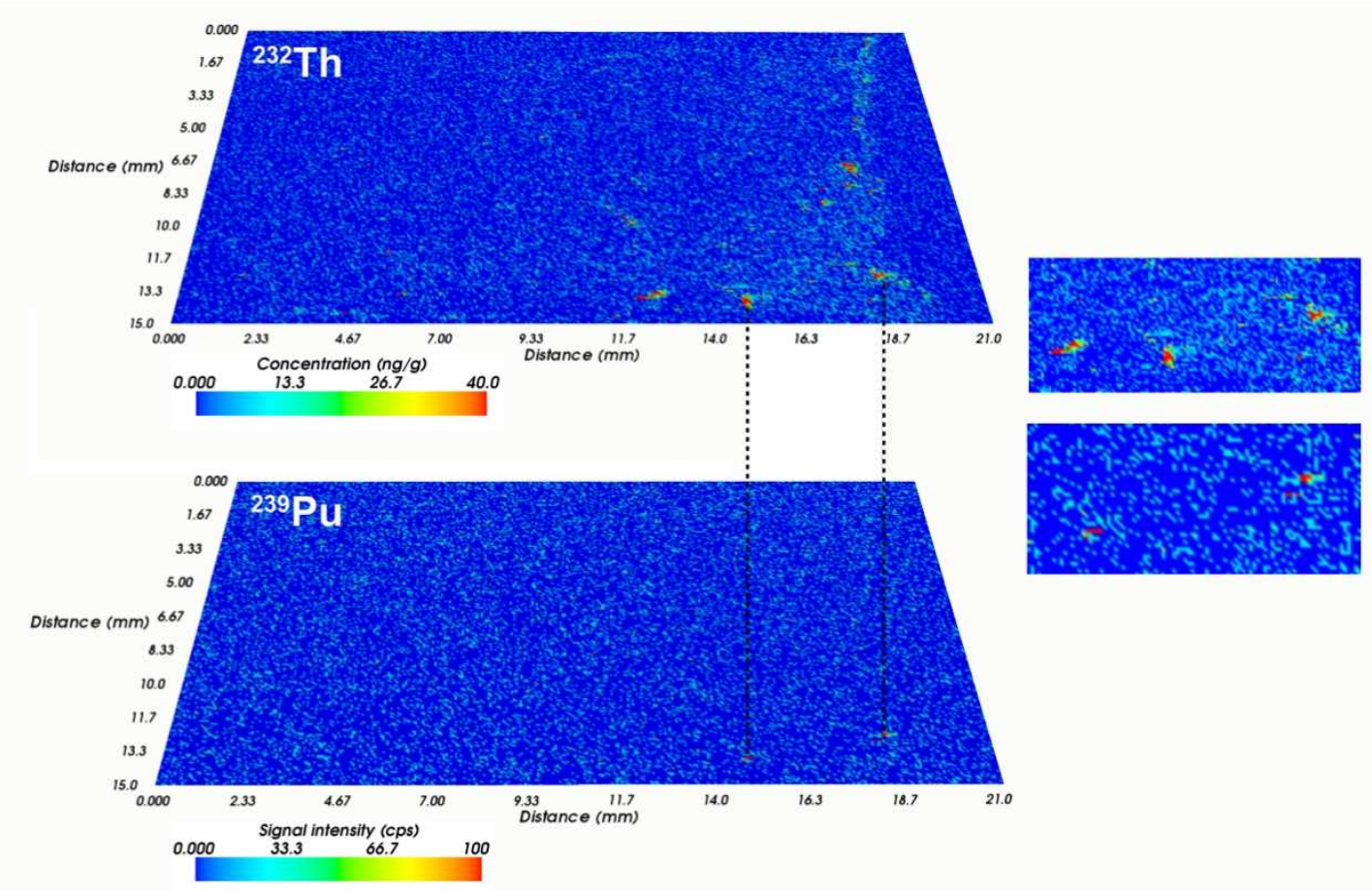

Figure 3: Corresponding m/z 232 and 239 particles in inferior right lung tissue in USTUR Case 0407. 


\section{USTUR Case 0303}

This Registrant had suffered a skin puncture wound contaminated with a soluble form of plutonium. This incident may also have released some airborne plutonium. The right tracheobronchial lymph node showed no detectable quantities of Pu-material at $\mathrm{m} / \mathrm{z} 239$ or 240 . This confirmed the soluble nature of any inhaled plutonium.

Figure 4 shows a distribution of ${ }^{232} \mathrm{Th}$ and ${ }^{238} \mathrm{U}$ in the lymph node ranging up to 400 and $375 \mathrm{ng} / \mathrm{g}$, respectively. Lateral image resolution was $65 \mu \mathrm{m}$. The Registrant did not work with these nuclides, and so the measured levels reflect his chronic (presumably natural) background inhalation exposure. These ${ }^{232} \mathrm{Th}$ and ${ }^{238} \mathrm{U}$ maximum concentrations are close to the values measured in the lymph node from Case 0407 of ( $300 \mathrm{ng} / \mathrm{g}$ and $200 \mathrm{ng} / \mathrm{g}$, respectively), who also did not work with these radionuclides. It was extremely unlikely that the measured ${ }^{232} \mathrm{Th}$ concentrations in the lymph node arose from adventitious exposure at the Rocky Flats and Hanford sites since this material was not involved in their production processes. The measured ${ }^{238} \mathrm{U}$ concentrations are similar to those of ${ }^{232} \mathrm{Th}$, and are thus also most likely to have arisen from chronic (natural) background inhalation of uranium. 
Figure 4: Photomicrograph (top) and m/z 232 and 238 images (65- $\mu \mathrm{m}$ scan spot) of right tracheobronchial lymph node from USTUR Case 0303.

\begin{abstract}
Americium exposure
USTUR Case 0246

${ }^{241} \mathrm{Am}$ was not detected in the section of right superior lung lobe analyzed here. This null observation is consistent with previous radiochemical ${ }^{241} \mathrm{Am}$ analyses $(3 \mathrm{~Bq} / \mathrm{g}$ or $0.024 \mathrm{ng} / \mathrm{g})$ in the right lung ${ }^{25}$. This concentration is well below the limit of detection of the currently used LA-ICP-MS system. However, as for the two earlier cases, inhomogeneous distributions of ${ }^{232} \mathrm{Th}$ and ${ }^{238} \mathrm{U}$, presumably from chronic natural background inhalation were observed, with concentrations ranging up to $200 \mathrm{ng} / \mathrm{g}$ and $100 \mathrm{ng} / \mathrm{g}$, respectively (Figure 5).
\end{abstract}


Figure 5: Photomicrograph (top) and ${ }^{232} \mathrm{Th}$ and ${ }^{238} \mathrm{U}$ images (65- $\mu \mathrm{m}$ scan spot) from superior right lung tissue from USTUR Case 0246.

\section{Uranium and thorium exposure}

\section{USTUR Case 1060}

The parabronchial lymph node from Case 1060 (Figure 6) showed $\sim 20-40$ times higher ${ }^{238} \mathrm{U}$ concentration than the lymph nodes from Cases 0303 and 0407 . Furthermore, ${ }^{235} \mathrm{U}$ was detected in the Case 1060 lymph node. The high measured values of ${ }^{238} \mathrm{U}$ and delectability of ${ }^{235} \mathrm{U}$, and low ${ }^{232} \mathrm{Th}$ are consistent with this Registrant's known occupational exposure to uranium but not to thorium.

Table 4 compares the maximum ${ }^{232} \mathrm{Th},{ }^{235} \mathrm{U}$ and ${ }^{238} \mathrm{U}$ concentrations measured for Case 1060 with those measured for the other three USTUR cases. 
Table 4. Comparison of ${ }^{232} \mathrm{Th},{ }^{235} \mathrm{U}$ and ${ }^{238} \mathrm{U}$ tissue concentrations from natural background and occupational uranium exposures in former nuclear workers

\begin{tabular}{|c|l|l|c|c|c|}
\hline \multirow{2}{*}{$\begin{array}{c}\text { USTUR } \\
\text { Sample \# }\end{array}$} & Tissue description & \multicolumn{2}{|l|}{$\begin{array}{c}\text { Type of } \\
\text { exposure }\end{array}$} & \multicolumn{2}{|l|}{ Maximum isotopic concentration, ng/g } \\
\cline { 4 - 6 } & & & ${ }^{232}$ Th & ${ }^{235} U$ & ${ }^{238} U$ \\
\hline 1060.304 & LN Parabronchial (L) & occupational ${ }^{\dagger}$ & 160 & 70 & 8500 \\
\hline 0246.610 & Lung (R) - Superior Lobe & chronic natural & 200 & N.D. $^{\ddagger}$ & 100 \\
\hline 0303.007 & LN Tracheobronchial (R) & chronic natural & 400 & N.D. & 375 \\
\hline 0407.002 & LN Paratracheal (R) & chronic natural & 300 & N.D. & 200 \\
\hline 0407.630 & Lung (R): Inferior & chronic natural & 40 & N.D. & 170 \\
\hline
\end{tabular}

$\dagger$ - chronic exposure to natural ${ }^{232} \mathrm{Th}, \ddagger$ - not detected

As shown in Table 4, the maximum concentration of ${ }^{232} \mathrm{Th}$ in lung from (presumed) natural background inhalation exposure ranged within $40-200 \mathrm{ng} / \mathrm{g}$ and within $160-400 \mathrm{ng} / \mathrm{g}$ in lymph node samples. No ${ }^{235} \mathrm{U}$ was detected in either lymph node or lung samples from cases with these low background exposures and the ${ }^{238} \mathrm{U}$ concentration in lungs $(100-170 \mathrm{ng} / \mathrm{g})$ was about half that in lymph nodes $(200-375 \mathrm{ng} / \mathrm{g})$.

USTUR Registrant 1060 was chronically exposed to uranium of natural composition at work ${ }^{3}$ for several years, with a single acute high-level exposure ${ }^{23}$.

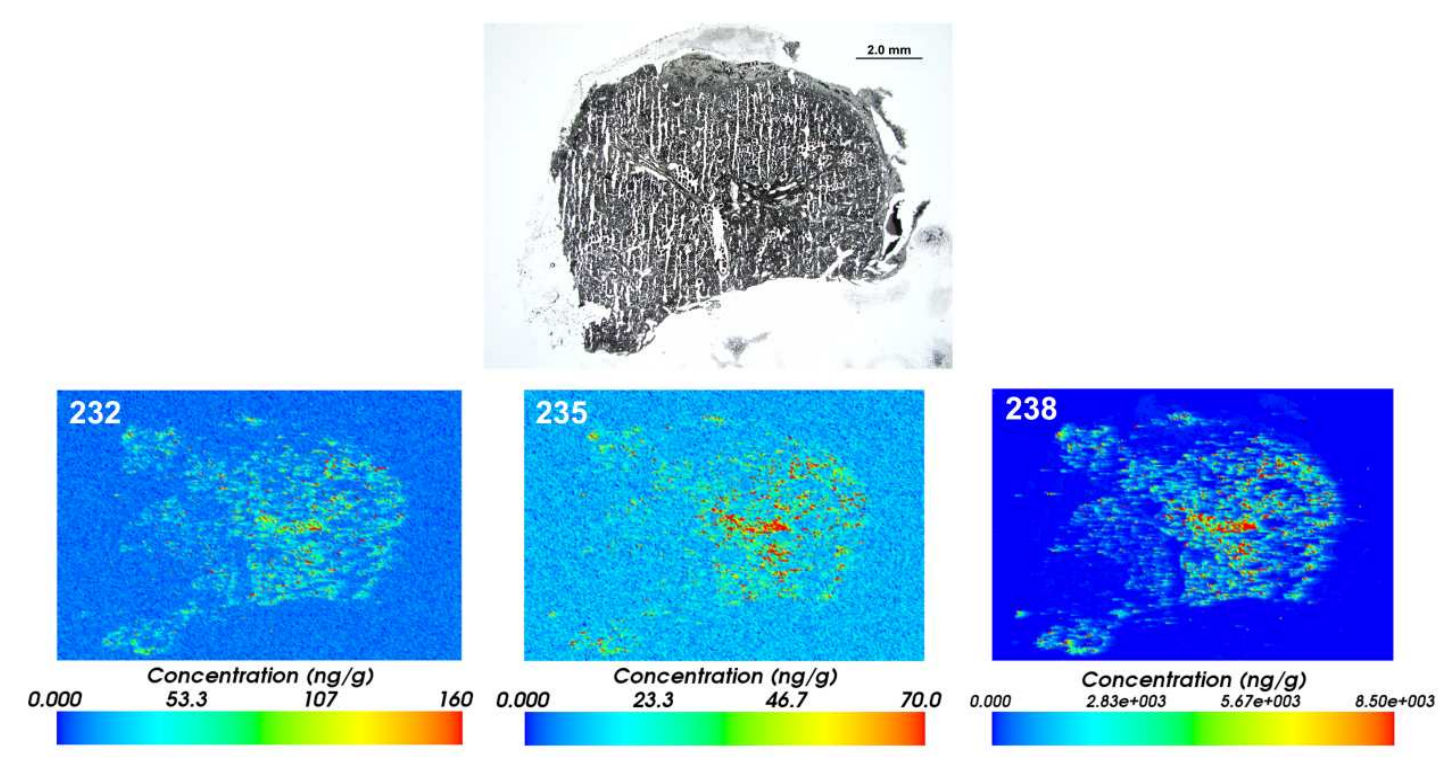

Figure 6: Photomicrograph (top) and $\mathrm{m} / \mathrm{z} 232,235$ and 238 images (30- $\mu \mathrm{m}$ scan spot) of left parabronchial lymph node from USTUR Case 1060. 
Case 1060 was also reported to have had exposure to airborne Pu on two occasions, although no ${ }^{239} \mathrm{Pu}$ or

${ }^{240} \mathrm{Pu}$ was detected in the lymph node. This null observation is consistent with the health physics monitoring data in this case, which recorded only one positive measurement of Pu in urine ${ }^{23}$. However, non-detection of any signal at $\mathrm{m} / \mathrm{z}=239$ in this high uranium exposure case (at $8500 \mathrm{ng} / \mathrm{g}{ }^{238} \mathrm{U}$ ) is important, since it confirms that the $\mathrm{m} / \mathrm{z}=239$ signal in Case 0407 is entirely attributable to the ${ }^{239} \mathrm{Pu}$ and not to ${ }^{238} \mathrm{UH}^{+}$isobaric interference.

\section{Conclusion}

Elemental bio-imaging by LA-ICP-MS is a useful tool for both visualization and quantitative determination of the localized mass concentrations of the actinide elements Th and $U$ in human tissues, for both chronic natural background and occupational exposures. For the first time, qualititative bio-imaging of ${ }^{239} \mathrm{Pu}$ and

${ }^{240} \mathrm{Pu}$ is demonstrated for lymph node and lung samples from an occupationally exposed person. The distributions of thorium, uranium and plutonium isotopes in all sections of lymph node and lung analyzed were highly inhomogeneous, indicating localized aggregation of the inhaled particles for both chronic natural background and acute occupational actinide exposures. This work provides a significant new capability to study the micro-distribution of long-lived actinides in human tissues, and thus directly address issues of non-uniformity of radiation dose. Furthermore, we are extending the method to the field of industrial hygiene for former nuclear workers, in particular to the localization and quantification of beryllium, and potentially asbestos, in lung and lymph nodes.

\section{References}

1. National Council on Radiation Protection and Measurements, lonizing radiation exposure of the population of the United States, NCRP Report No. 160, 2009, Bethesda, MD.

2. Lynch, T.P.; Tolmachev, S.Y.; James, A.C. Radiat. Prot. Dosim. 2009, 134, 94-101.

3. Adley, F.E.; Gill, W.E.; Scott, R.H. Study of atmospheric contaminiation in the melt plant buiding. HW-23352(Rev.) United States Atomic Energy Commission; 1952, 1-97

4. James, A.C.; Brooks, B.G. in: Proceedings of the Fourth JAEA-US EPA Workshop on Radiation Risk Assessment, Tokai Research and Development Center, JAEA, Japan, November 7-8, 2006. Available at: http://www.ustur.wsu.edu/Conferences/2006/2006_JAEA-USDOE.html

5. Hare, D.; Reedy, B.; Grimm, R.; Wilkins, S.; Volitakis, I.; George, J.; Cherny, R.A.; Bush, A.I.; Finkelstein, D.I.; Doble, P. Metallomics 2009, 1, 53-58.

6. Austin, C.; Hare, D.; Rozelle, A.R.; Robinson, W.H.; Grimm, R.; Doble, P. Metallomics 2009, 1 142147.

7. Hare, D.; Burger, F.; Austin, C.; Fryer, F.; Grimm, R.; Reedy, B.; Scolyer, R.A.; Thompson, J.F.; Doble, P. Analyst, 2009, 134, 450-453.

8. Filipy, R.E.; Khokhryakov, V.F.; Suslova, K.G.; Romanov, S.A.; Stuit, D.B.; Aladova, E.E.; Kathren, R.L. J Radioanal Nucl Chem 1998, 234, 171-174.

9. Igarashi, Y.; Seki, R.; Ikeda, N. J Radiat Res, 1986, 27, 213-218.

10. Pappas, R.S.; Ting, B.G.; Jarrett, J.M.; Paschal, D.C.; Caudill, S.P.; Miller, D.T. J Anal Atom Spectrom, 2002, 17, 131-134. 
11. Ting, B.G.; Paschal, D.C.; Jarrett, J.M.; Pirkle, J.L.; Jackson, R.J.; Sampson, E.J.; Miller, D.T.; Caudill, S.P. Environ Res, 1999, 81, 45-51.

12. Tolmachev, S.; Kuwabara, J.; Noguchi, H. Health Phys, 2006 91, 144-53.

13. Wyse, E.J.; MacLellan, J.A.; Lindenmeier, C.W.; Bramson, J.P.; Koppenaal, D.W. J Radioanal Nucl Chem, 1998, 234, 165-70.

14. Tolmachyov, S.; Kuwabara, J.; Noguchi, H. J Radioanal Nucl Chem, 2004, 261, 125-131.

15. Li, C.S.; Benkhedda, K.; Varve, Z.; Kochemin, V.; Sadi, B.; Lai, E.; Kramer, G.; Cornett, J. J Anal Atom Spectrom, 2009, 24, 1429-1433.

16. Zoriy, M.V.; Kayser, M.; Izmer, A.; Pickhardt, C.; Becker, J.S. Int J Mass Spectrom, 2005, 242, 297302.

17. Zoriy, M.V.; Dehnhardt, M.; Reifenberger, G.; Zilles, K.; Becker, J.S. Int J Mass Spectrom, 2006, 257, 27-33.

18. Becker, J.S.; Zoriy, M.V.; Pickhardt, C.; Palomero-Gallagher, N.; Zilles, K. Anal Chem, 2005, 77,208216.

19. Becker, J.S.; Dobrowolska, J.; Zoriy, M.; Matusch, A. Rapid Commun Mass Sp, 2008, 22, 27682772.

20. USTUR 0407: Rocky Flats - 1965 Acute Inhalation (Fire) - Refractory ${ }^{239} \mathrm{Pu}$ - Chelated: Narrative. United States Transuranium and Uranium Registries. 14 May 2009. Washington State University: College of Pharmacy. Accessed 8 November 2009. Available at: http://www.ustur.wsu.edu/Case_Studies/Narratives/0407_Narrative.php

21. USTUR 0303: Hanford - 1968 Puncture Wound - Soluble ${ }^{239} \mathrm{Pu}$ - Chelated: Narrative. United States Transuranium and Uranium Registries. 14 May 2009. Washington State University: College of Pharmacy. Accessed 8 November 2009. Available at: http://www.ustur.wsu.edu/Case_Studies/Narratives/0303_Narrative.php.

22. USTUR 0246: Hanford - 1976 Wound - ${ }^{241} \mathrm{Am}$ - Chelated: Narrative. United States Transuranium and Uranium Registries. 20 May 2009. Washington State University: College of Pharmacy. Accessed 8 November 2009. Available at: http://www.ustur.wsu.edu/Case_Studies/Narratives/0246_McCluskey.php.

23. USTUR 1060: Hanford - late 1940s Chronic Inhalation $-\mathrm{U}_{3} \mathrm{O}_{8}-$ Not Chelated: Narrative. United States Transuranium and Uranium Registries. 9 July 2009. Washington State University: College of Pharmacy. Accessed 8 November 2009. Available at: http://www.ustur.wsu.edu/Case_Studies/Narratives/1060_Narrative.php.

24. Kelley, J.M.; Bond, L.A.; Beasley, T.M. Sci Total Environ, 1999, 238, 483-500.

25. McInroy, J.F.; Kathren, R.L.; Toohey, R.E.; Swint, M.J.; Breitenstein, Jr., B.D. Health Phys, 1995, 69, 318-323. 